\title{
A preliminary characterisation of the habitat use and feeding of Allis shad (Alosa alosa) juveniles in the Minho River tidal freshwater wetlands
}

\author{
Micaela Mota ${ }^{1,2,3, *}$ and Carlos Antunes ${ }^{2,3,4}$ \\ ${ }^{1}$ ICBAS-Instituto de Ciências Biomédicas Abel Salazar; Universidade do Porto, Largo Prof. Abel Salazar 2, \\ 4099-003 Porto, Portugal. \\ 2 CIMAR/CIIMAR-Centro Interdisciplinar de Investigação Marinha e Ambiental; Universidade do Porto, Rua \\ dos Bragas 289, 4050-123 Porto, Portugal. \\ 3 Aquamuseu do Rio Minho, Parque do Castelinho, 4920-290 Vila Nova de Cerveira, Portugal. \\ ${ }^{4}$ ESG-Escola Superior Gallaecia, Largo das Oliveiras, 4920 V. N. Cerveira, Portugal. \\ * Corresponding author: mmota@ ciimar.up.pt
}

Received: 20/10/2010

Accepted: 30/1/12

\begin{abstract}
A preliminary characterisation of the habitat use and feeding of Allis shad (Alosa alosa) juveniles in the Minho River tidal freshwater wetlands

The availability of high-quality rearing areas and survival during the early life-history stages are considered key factors determining the number of recruits produced and are prerequisites for the successful recruitment of several fish species. To identify the freshwater habitat use of Allis shad, several samples were collected in the tidal and non-tidal freshwater areas of the Minho River during the autumn of 2009. The two places where juveniles were found are substantially different in terms of sediment texture and organic matter but similar in depth and water current velocities. The food items found in the stomach contents may indicate that movements of juveniles occur in the estuary.
\end{abstract}

Key words: Allis shad, Juveniles, Habitat, Freshwater stage, Conservation.

\section{RESUMEN}

Caracterización preliminar del hábitat y alimentación de juveniles de sábalo (Alosa alosa) en la zona de mareas de agua dulce del río Miño

La disponibilidad de áreas de crecimiento adecuadas y la supervivencia de las primeras etapas de vida de los peces están consideradas factores clave para determinar la abundancia de diferentes especies. Con el fin de identificar áreas de crecimiento de juveniles de sábalo, se han realizado en el otoño de 2009 varios estudios de campo a lo largo de la zona de agua dulce que se encuentra afectada, o no, por las mareas del río Miño. Las dos zonas donde se han encontrado juveniles difirieron considerablemente en la textura de los sedimentos y materia orgánica, pero eran similares en profundidad y velocidad de corrientes. Los alimentos encontrados en el contenido estomacal sugieren la existencia de movimientos en el estuario.

Palabras clave: Sábalo, juveniles, hábitat, etapa de agua dulce, conservación. 


\section{INTRODUCTION}

Diadromous fishes have suffered dramatic population declines over the past century in Europe as well as in North America (Ross \& Bennett, 1997; Limburg \& Waldman, 2009). The Allis shad Alosa alosa (Linnaeus 1758) is an anadromous fish of the family Clupeidae. This species has been progressively disappearing from European rivers. The main causes of such declines are dam construction, sediment loading, pollution and habitat alteration or loss. The larvae and juveniles rear in freshwater, and juveniles migrate to the ocean before age 1 and mature in the ocean. Young-of-the-year (YOY) Allis shad migrate downstream in schools during the summer and fall of the first year of life. The migration lasts from 3 to 6 months (Taverny et al. 2000; Baglinière et al., 2003). In Europe, early life stage studies have been performed on the estuarine phase and discrimination of the natal origin of YOY Allis shad (Tomás et al., 2005; Lochet et al., 2009) and on the feeding ecology of juvenile Twaite shad Alosa fallax (Lacépède) habitat (Aprahamian, 1989; Assis et al., 1992; Oesmann $\&$ Thiel, 2001). However, habitat use and requirement studies have not yet been specifically addressed for pre-migratory YOY Allis shad in riverine habitat. Indeed, at the European level, little is known about the distribution and characterisation of the freshwater and estuarine habitats that are important to the rearing of Allis shad in its early life stage.

Because habitat loss is one of the main causes for population decline, the survival and availability of rearing areas in the early life stages could be considered a key factor determining the abundance of YOY Allis shad.

Therefore, the aims of this study were to perform a preliminary study of freshwater habitat use by YOY Allis shad to investigate the following topics: (1) to identify the Minho River's freshwater and tidal freshwater wetland (TFW) habitats occupied by juvenile Allis shad; (2) to characterise the habitats of importance for the growth of the species in its early life in freshwater, including such physical aspects as sediment texture (granulometry) and water current veloc- ity and depth; and (3) to examine the diet of the juvenile stages in those habitats.

\section{MATERIALS AND METHODS}

\section{Study area}

The Minho River is an international water body on the northwestern Iberian Peninsula. Its watershed covers $17080 \mathrm{~km}^{2}$, and its main course is approximately $300 \mathrm{~km}$ long. The last $77 \mathrm{~km}$ of the river forms the natural northwestern boundary between Portugal and Spain and is currently the only free segment for the upstream migration and spawning of Allis shad and other diadromous fish (between the river mouth and the first dam, located in Spain). The Minho estuary is $40 \mathrm{~km}$ long and has a maximum width of slightly greater than $2 \mathrm{~km}$ near the river mouth. The salt intrusion in the estuary extends from approximately $11.3 \mathrm{~km}$ and up to $16.8 \mathrm{~km}$ inland during higher spring tides (September).

Tidal Freshwater Wetlands (TFWs) are found in the $29 \mathrm{~km}$ upstream stretch. The study area was located between the Minho River TFWs and the spawning area (personal observation) approximately $80 \mathrm{~km}$ from the river mouth, near the first dam (Fig. 1).

\section{Sampling strategy}

The potential rearing habitats of juvenile A. alosa were investigated along the Minho River TFWs and the spawning area during autumn 2009. At three sites near the spawning grounds and two sites in the TFWs, a beach seine net $(10 \mathrm{~mm}$ mesh, bag $4.8 \mathrm{~m}$ in length, $3 \mathrm{~m}$ mouth width, wings $6 \mathrm{~m}$ in length and $2.4 \mathrm{~m}$ in height) was used to sample the YOY Allis shad. The sampling effort was distributed over the daylight hours and the night. During each sampling period, the water temperature was recorded with a YSI 6820 multiparameter meter (USA).

\section{Habitat characterisation}

In the field, YOY Allis shad were collected and quickly stored under refrigeration before trans- 


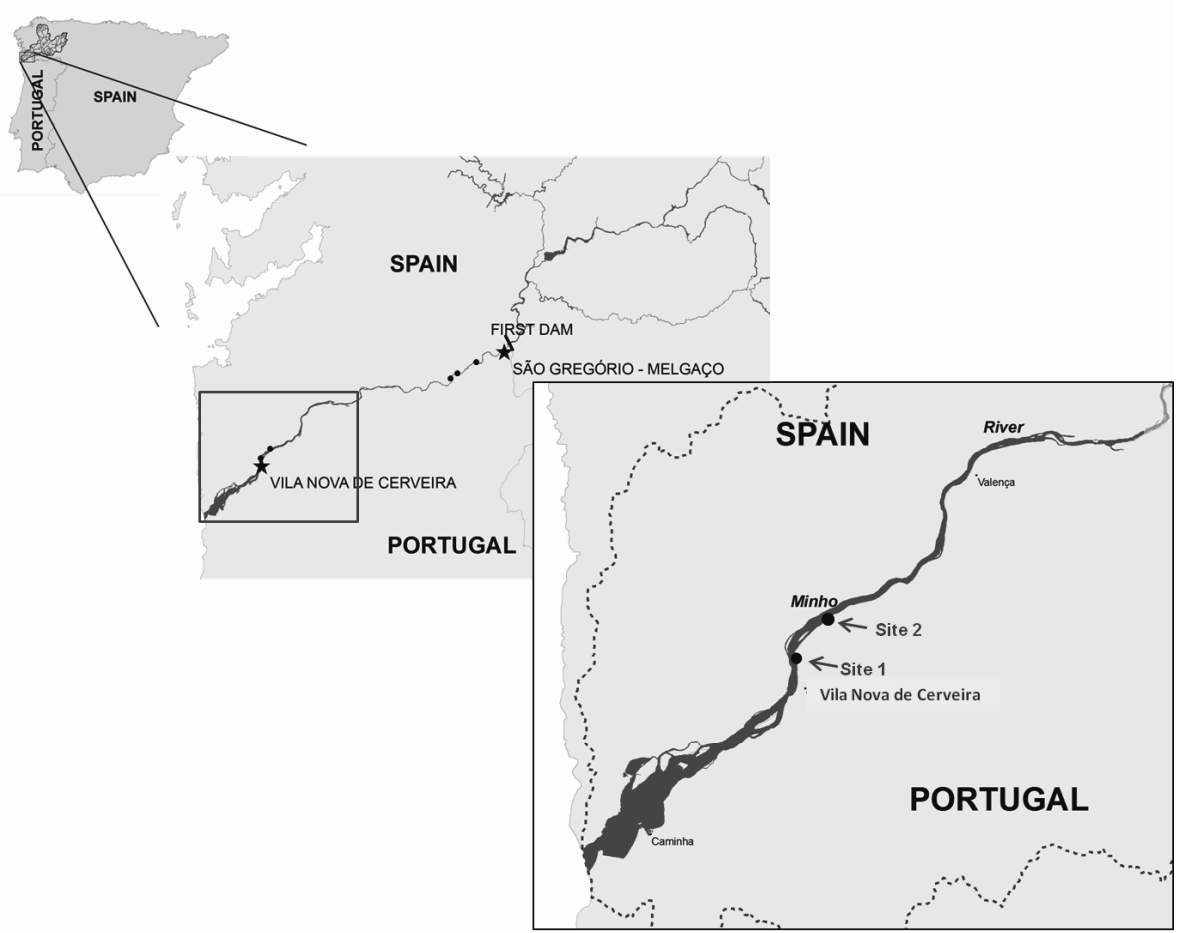

Figure 1. Map of the study area showing the location of the non-tidal and TFW sampling sites (dots). Site 1 and Site 2 are the two TFW sites at which YOY Allis shad were found (arrows). Mapa del área de estudio indicando los emplazamientos de muestreo que se encontraban bajo la influencia de mareas o no (puntos). El Emplazamiento 1 y Emplazamiento 2 fueron los locales donde se observó la presencia de juveniles de sábalo (flechas).

port to the laboratory. The fish were labelled, measured $( \pm 0.1 \mathrm{~mm})$ fork length $(\mathrm{FL})$ and total length (TL)-and weighed ( $\pm 0.01 \mathrm{~g}$ wet mass). The length-class frequencies were calculated for the total sample of fish. A two-way ANOVA was performed to evaluate differences in total lengths between months and sampling sites. The catch per unit effort (CPUE) was calculated for each sampling site. The CPUE was obtained by the standardisation, to each month and site, of the number of individuals caught per unit area (ha).

The digestive tracts of all YOY caught were excised and preserved in $70 \%$ alcohol for stomach content analysis, and food items were counted and identified up to the lowest taxonomic level possible. The relative importance of each prey item in the diet was evaluated by two indices (data from the two sampling sites separately): the numerical index (NI) - the percentage of the number of individuals of a prey over the total number of individuals of all prey, and the occurrence index $(\mathrm{OI})$ - the percentage of non-empty stomachs in which a prey occurred over the total number of occurrences (Hyslop, 1980). The remaining biological material was frozen for subsequent isotopic analysis of muscle and for otolith extraction.

The two sampling sites where the presence of YOY Allis shad was verified (site 1 and site 2, both located in the TFWs) (Fig. 1) were characterised in relation to the following physical variables: the texture of the sediment, current velocity and depth. Transects perpendicular to the edge, 7 meters apart, were performed in an area of approximately $1100 \mathrm{~m}^{2}$ at sampling site 2 and $600 \mathrm{~m}^{2}$ at sampling site 1 . At 3-meter intervals within each transect, sediment samples for granulometry and organic matter content analysis were collected and the depth was recorded. The granulometry was analysed after oven drying the sediment for 72 hours. The dried sediment was placed on a column of sieves with different 
mesh sizes, in descending order from top to bottom, according to the Wentworth scale (Mudroch $\&$ Azcue, 1995) and sieved. The frequency of each sieved fraction was expressed as a percentage of total weight, and the cumulative percentage was calculated. The organic matter content of the sediment was determined after combustion in a muffle furnace for 4 hours at $550{ }^{\circ} \mathrm{C}$. The organic matter was expressed as a percentage of the weight loss of each sample after incineration.

For the first and last transect of each sampling site, the current velocity was recorded with a flow meter (Valeport BFM001) at the bottom, middle and surface of the water column.

\section{RESULTS}

YOY Allis shad were only caught in November and December 2009, during the night, at the two sampling sites located in the Minho River TFWs (Fig. 1): site $1\left(41^{\circ} 57^{\prime} 100^{\prime \prime} \mathrm{N}\right.$; at $14 \mathrm{~km}$ from the river mouth) and site $2\left(41^{\circ} 58^{\prime} 501^{\prime \prime} \mathrm{N}\right.$; at $16.7 \mathrm{~km}$ from the river mouth). YOY Allis shad were not found in the sampling sites located near the spawning grounds or in any sites sampled during the day.

A total of 228 fish were caught. Of these fish, 215 were from site 1 , and 13 were from site 2 (Fig. 1). Accordingly, the CPUE is higher for site 1 in both months (Fig. 2).

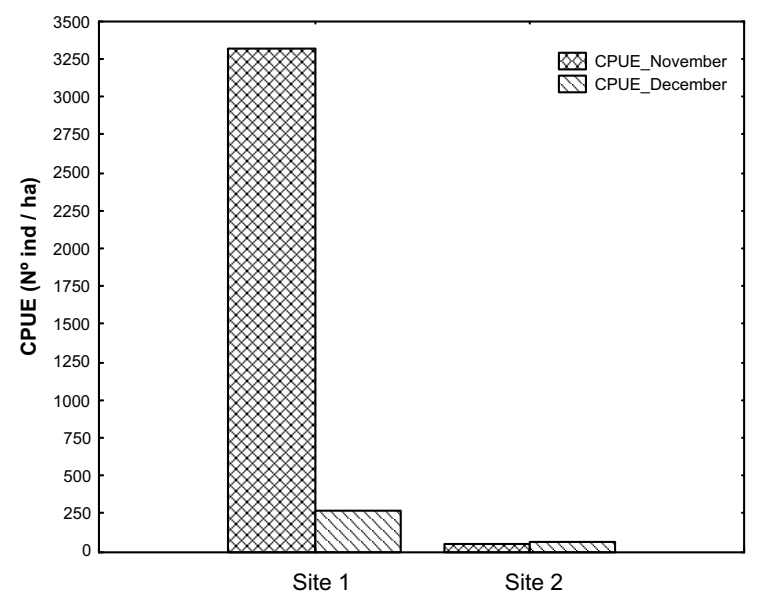

Figure 2. Comparison of the CPUE (number of individuals/ha) between months and sampling sites. Comparativa del CPUE ( $n^{o}$ individuos/ha) entre los emplazamientos y los meses de muestreo.

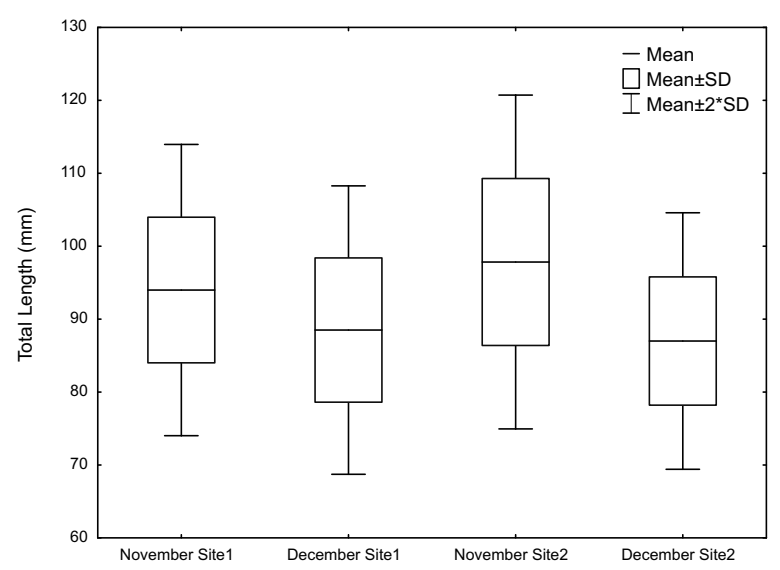

Figure 3. Boxplot of the average total length of YOY Allis shad by site and month. Longitud total media de los juveniles de sábalo muestreados por emplazamiento y por mes.

The average total length of the fish at each site and in each month is shown in figure 3 . The average total lengths of the YOY Allis shad differ significantly between months $(p=0.009)$. The average total lengths are higher in November than in December. However, the differences among sites as well as among sites and months are not significant $(p>0.05)$. The length-class frequencies calculated for the entire sample are shown in figure 4. The most common length class is 9.1$10 \mathrm{~cm}$, followed by $8.3-9.1 \mathrm{~cm}$.

Table 1 lists the prey items found in the stomach analyses at each site and the corresponding values of the diet indices. The numerical and occurrence indices show Corophium sp. as the most

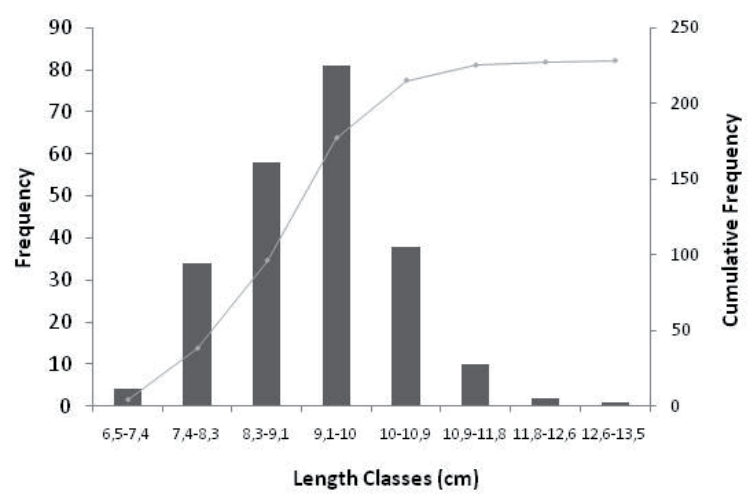

Figure 4. Length-class frequencies of all the fish caught at both sampling sites. $N=228$. Frecuencia de las clases de longitud del total de ejemplares capturados en los dos emplazamientos de muestreo. $\mathrm{N}=228$. 
Table 1. Composition of food items in the stomachs of YOY Allis shad. Site $1 N=215$; Site $2 N=13$. NI-Numerical Indices; OI-Occurrence Indices. Composición de los alimentos identificados en los contenidos estomacales de juveniles de sábalos. Emplazamiento $1 \mathrm{~N}=215$; Emplazamiento $2 \mathrm{~N}=13$. NI-Índice Numérico; OI-Índice de ocurrencia.

\begin{tabular}{|c|c|c|c|c|}
\hline & \multicolumn{2}{|c|}{ Site 1} & \multicolumn{2}{|c|}{ Site 2} \\
\hline & NI & OI & NI & OI \\
\hline \multicolumn{5}{|l|}{ Arachnida } \\
\hline Not identified & 0.0 & 0.0 & 2.2 & 33.3 \\
\hline \multicolumn{5}{|l|}{ Crustacea } \\
\hline Not identified & 0.0 & 0.0 & 4.4 & 33.3 \\
\hline Amphipoda (not identified) & 0.1 & 2.1 & 0.0 & 0.0 \\
\hline Atyaephyra desmarestii & 4.1 & 29.8 & 0.0 & 0.0 \\
\hline Corophium sp. & 90.7 & 100.0 & 13.3 & 66.7 \\
\hline Gammaridae (not identified) & 2.3 & 42.6 & 0.0 & 0.0 \\
\hline Gammarus sp. & 2.2 & 23.4 & 11.1 & 33.3 \\
\hline Saduriela sp. & 0.1 & 2.1 & 0.0 & 0.0 \\
\hline \multicolumn{5}{|l|}{ Collembola } \\
\hline Not identified & 0.0 & 0.0 & 26.7 & 66.7 \\
\hline \multicolumn{5}{|l|}{ Insecta } \\
\hline Adult not identified & 0.0 & 0.0 & 6.7 & 66.7 \\
\hline Chironomidae & 0.3 & 10.6 & 11.1 & 100.0 \\
\hline Coleoptera & 0.0 & 0.0 & 2.2 & 33.3 \\
\hline Diptera (nymph) & 0.1 & 4.3 & 13.3 & 66.7 \\
\hline Ephemeroptera & 0.0 & 0.0 & 2.2 & 33.3 \\
\hline Plecoptera & 0.1 & 4.3 & 2.2 & 33.3 \\
\hline Simuliidae & 0.0 & 0.0 & 4.4 & 33.3 \\
\hline Trichoptera & 0.1 & 2.1 & 0.0 & 0.0 \\
\hline
\end{tabular}

important food item at site 1 , whereas it is the second most important at site 2 according to the numerical and occurrence indices. According to the numerical index, dipteran nymphs are also the second most important group at site 2 . According to the occurrence index, dipteran nymphs, insect adults, Corophium sp. and Collembola are the second most important groups at site 2 . At site 2 , the Chironomidea group occur in all of the stomachs. However, the Collembola group is the most numerous at site 2 , followed by Corophium sp. and dipteran nymphs.

The physical characteristics of the habitat at site 1 and site 2 show both similarities and dissimilarities. The water at both sites is quite deep. The water depth at site 2 is slightly greater than the depth at site 1 ( $8 \mathrm{~m}$ maximum and $7 \mathrm{~m}$ maximum, respectively). The current velocity at the sampling sites is lower than the current velocity in the main channel (average $0.3 \mathrm{~m} / \mathrm{s}$ at site 1 and $0.02 \mathrm{~m} / \mathrm{s}$ at site 2, compared with $0.85 \mathrm{~m} / \mathrm{s}$ in the channel). In addition, both sites include an upstream area with semi-emergent rocks. This feature gives the sites the appearance of a pool.

The sediment grain size and organic matter content differ substantially between the two sites. The two sites differ greatly in the dominant granule fraction (Fig. 5). The dominant fraction is $1 \mathrm{~mm}-0.5 \mathrm{~mm}$ at site 1 and $0.25 \mathrm{~mm}-0.125 \mathrm{~mm}$ at site 2 . As expected, the percentage of organic matter in the sediment is higher at site $2(3.85 \%)$ than at site $1(0.67 \%)$.

\section{DISCUSSION}

Since the middle of the $20^{\text {th }}$ century, the habitat available for the upstream migration of the Minho River A. alosa has decreased substantially due to dam construction and currently includes 


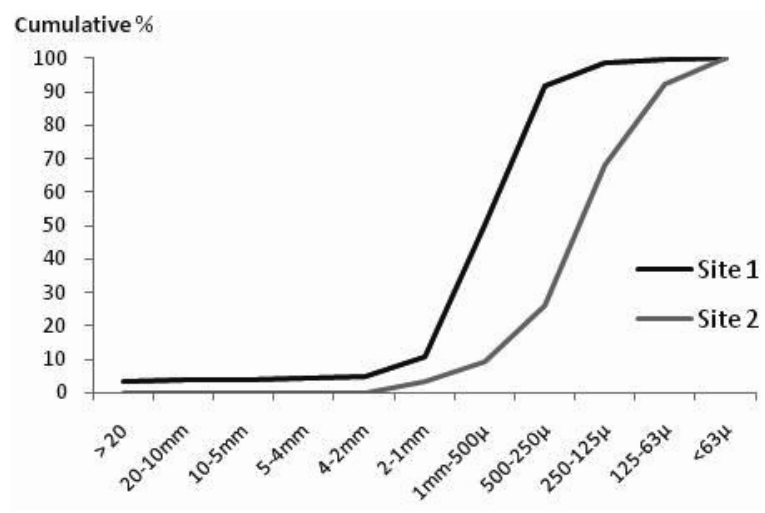

Figure 5. Cumulative percentages of sediment grain-size fractions at Site 1 and Site 2. Frecuencia acumulada de las fracciones del tamaño de gránulos de los sedimentos de los emplazamientos 1 y 2 .

only $80 \mathrm{~km}$ (from the estuary to the first dam) of the existing $300 \mathrm{~km}$. As the loss of habitat is a reality, it is of extreme importance to identify and preserve the areas appropriate for the high-quality development of the early life stages of Allis shad.

The absence of juveniles in the samples collected at the 3 upstream sites, near the spawning area, might be explained by the sites selected, the hour of the day or the sampling methodology. Intensive research on rearing habitat in the upstream area should be performed. Sampling at night should be emphasised because catchability appears to be greater at night.

The CPUE was exceptionally high at site 1 in November relative to the other capture data. It is possible that gregarious behaviour may facilitate a greater catch in the preferred habitats. Isolated captures of juvenile Allis shad are described as a by-catch component in the glass eel fishery (Antunes \& Weber, 1996).

The results of this study describing diet and food preferences agree with those reported by Taverny et al. (2000). The YOY Allis shad appear to be euryphagous, using a broad range of trophic resources accessible in the upstream and estuarine environments. Ross \& Bennett (1997) demonstrated that American shad (Alosa sapidissima) prey selection is opportunistic, as this species feeds on a variety of aquatic and terrestrial prey taxa. Crustaceans appear to be an important item in the juveniles' diet. Oesman \& Thiel (2001) described copepods, mysids and fish as the principal food items of juvenile Twaite shad in the Elbe estuary. Aprahamian (1989) reported copepods, mysids and gammarids as the principal food items of juvenile Twaite shad in the Severn Estuary. The results of the current study suggest that amphipods are the preferred item, but this tendency is not statistically significant. Fish were absent from the diet of the YOY Allis shad. The subtidal macrozoobenthic study performed by Sousa et al. (2008) in the Minho River did not detect brackish-water organisms (e.g., Corophium sp.) in the upper TFWs. The presence of food items typical of brackish areas in the stomach contents of the juveniles sampled at site 2 may indicate that the juveniles move within the estuary. However, this conclusion should be viewed with caution due to the low number of fish caught at this sampling site. It is necessary to recognise that the hypothetical movements of the juveniles can only be confirmed through isotopic analysis.

The two TFW locations at which the juveniles were found differ substantially in sediment texture and organic matter but are similar in depth and low current velocities compared with the main channel. Although juveniles were captured at few sites, the study showed that YOY Allis shad occur in deep pools close to the bank, where the faster river currents can be avoided. Aprahamian (1981) found similar behaviour in young Twaite shad (A. fallax). Because YOY Allis shad appear to be generalists and/or opportunists in their prey selection, the physical characteristics of the habitat, such as the water column depth and current velocity, may be a more important aspect of the juveniles' choice of rearing area than the availability and/or types of prey items present in these areas.

Future investigations will be conducted to integrate the variables describing the biotic processes (e.g. the availability and abundance of prey and competitors) and to estimate the residence times of the YOY Allis shad in freshwater, tidal freshwater and brackish habitats. These investigations will be performed by determining the changes in the stable isotope ratios that occur when the juveniles migrate seawards from the freshwater habitat to a new habitat. The ultimate 
objective is to determine the most important ecological characteristics of the freshwater habitat and to map these characteristics as well as the geological and topographic characteristics of the habitat.

A better understanding of the specific abiotic and biotic upstream and estuarine habitat requirements for the growth of YOY Allis shad should allow managers to plan conservation and protection strategies for such areas.

\section{ACKNOWLEDGEMENTS}

Micaela Mota is supported by a $\mathrm{PhD}$ grant from the Portuguese Foundation for Science and Technology-FCT (SFRH/BD/44892/2008). We especially thank Eduardo Martins, Eugénio Pereira, Rita Carvalho, Vânia Gonçalves and António Roleira for field assistance, Sandra Fernandes and Sofia Ribeiro for laboratory assistance, Claudio Ramos for producing the map of the study area, Jonathan Wilson for helpfully providing an English version of the manuscript and Pedro Seixas for helpfully providing a Spanish version. The authors thank associate editor García-Berthou and the reviewers for their constructive comments.

\section{REFERENCES}

ANTUNES, C. \& M. WEBER. 1996. The glass eel fishery and the by-catch in the Rio Minho after one decade (1981-1982 and 1991-1992). Archives of Polish Fisheries, 2a: 131-139.

APRAHAMIAN, M. W. 1981. Aspects of the biology of the twaite shad (Alosa fallax) in the rivers Severn and Wye. Proceedings of the Second British Freshwater Fish Conference. Liverpool, England: 2; 373-381.

APRAHAMIAN, M. W. 1989. The diet of juvenile and adult twaite shad Alosa fallax fallax (Lacépède) from the rivers Severn and Wye (Britain). Hydrobiologia, 179: 173-182.

ASSIS, C. A., P. R. ALMEIDA, F. MOREIRA, J. L.
COSTA \& M. J. COSTA. 1992. Diet of the twaite shad Alosa fallax (Lacépède) (Clupeidae) in the River Tagus Estuary, Portugal. J. Fish Biol., 41: 1049-1050.

BAGLINIÈRE, J. L., M. R. SABATIÉ, E. ROCHARD, P. ALEXANDRINO \& M. W.APRAHAMIAN. 2003. The Allis Shad Alosa alosa: Biology, Ecology, Range, and Status of Populations. American Fisheries Society Symposium, 35: 85-102.

HYSLOP, E. J. 1980. Stomach content analysis: a review of methods and their application. J. Fish Biol., 17: 415-429.

LIMBURG, K., \& J. WALDMAN. 2009. Dramatic declines in North Atlantic Diadromous fishes. BioScience, 59: 955-965.

LOCHET, A., S. BOUTRY \& E. ROCHARD. 2009. Estuarine phase during seaward migration for allis shad Alosa alosa and twaite shad Alosa fallax future spawners. Ecology of Freshwater Fish, 18: 323-335.

MUDROCH, A. \& J. M. AZCUE. 1995. Manual of Aquatic Sediment Sampling. Lewis Publishers. Florida. 219 pp.

OESMANN, S. \& R. THIEL. 2001. Feeding of juvenile twaite shad (Alosa fallax Lacépède, 1803) in the Elbe estuary. Bull. Fr. Pêche Piscic., 362/363: 785-800.

ROSS, R. M. \& R. M. BENNETT. 1997. Habitat use and feeding ecology of riverine juvenile American shad. North American Journal of Fisheries Management, 17: 964-974.

SOUSA, R., S. DIAS, V. FREITAS \& C. ANTUNES (2008). Subtidal macrozoobenthic assemblages along the River Minho estuary gradient (north-west Iberian Peninsula). Aquatic Conserv: Mar. Fhreshw. Ecosyst., 18: 1063-1077.

TAVERNY, C., J. J. CASSOU-LEINS, F. CASSOULEINS \& P. ELIE. 2000. De l'oeuf à l'adulte en mer. In: Les aloses (Alosa alosa et Alosa fallax spp.). J. L. Baglinière \& P. Elie (eds.): 93-124. INRA-Cemagref. Paris, France.

TOMAS, J., S. AUGAGNEUR \& E. ROCHARD. 2005. Discrimination of the natal origin of youngof-the-year Allis shad (Alosa alosa) in the Garonne-Dordogne basin (south-west France) using otolith chemistry. Ecology of Freshwater Fish, 14: 185-190. 